УдК [504.43+504.73].054: 547.912

doi: 10.31140/j.vestnikib.2016.4(198).4

\title{
НАКОПЛЕНИЕ ПОЛИЦИКЛИЧЕСКИХ АРОМАТИЧЕСКИХ УГЛЕВОДОРОДОВ РАСТЕНИЯМИ ЮЖНОЙ ТУНДРЫ ПРИ ДОБЫЧЕ УГЛЯ ОТКРЫТЫМ СПОСОБОМ
}

\author{
Е.В. Яковлева, Д.Н. Габов, В.А. Безносиков \\ Федеральное государственное бюджетное учреждение науки \\ Институт биологии Коми научного центра Уральского отделения РАН, Сыктывкар \\ E-mail: kaleeva@ib.komisc.ru
}

\begin{abstract}
Аннотация. Методом высокоэффективной жидкостной хроматографии проведено определение содержания полициклических ароматических углеводородов (ПАУ) в почвах и растениях полосы южной тундры в условиях аэротехногенного воздействия. Выявлены закономерности аккумуляции полиаренов растениями на фоновом участке и в зоне действия угольной шахты открытого типа. Установлено, что в почвах и растениях фонового и аэротехногенно загрязненного участков, как и в угле, основную долю ПАУ составляют низкомолекулярные полиарены. Определены наибольшие кратности превышения содержания тяжелых ПАУ, что связано с их минимальным содержанием на фоновых участках. Показано, что содержание бенз[а]пирена в растениях изменялось аналогично изменению суммарного содержания ПАУ. Наибольшая массовая доля ПАУ в растениях кустарниковой тундры сосредоточена в Pleurozium schreberi. Вклад растений верхнего яруса в суммарное накопление ПАУ растениями незначителен, при этом распределение полиаренов по органам модельных растений неравномерное и определяется их биоморфологическими особенностями и уровнем загрязнения.
\end{abstract}

Ключевые слова: полициклические ароматические углеводороды, угледобывающая промышленность, тундра, почва, растения

\section{Введение}

Полициклические ароматические углеводороды (ПАУ) представляют собой органические соединения бензольного ряда, различающиеся по числу бензольных колец и особенностям их присоединения (Клар, 1971). ПАУ образуются в природных экосистемах и их компонентах, включая почвы, в результате биогеохимической трансформации органического вещества, а также имеют антропогенное происхождение (как результат неполного сгорания органических материалов). Это способствует постоянному присутствию данных соединений в объектах окружающей среды. Известно, что одним из главных исходных продуктов для образования ПАУ служат нефть, нефтепродукты, угли, горючие газы, используемые в качестве химического сырья и топлива на промышленных предприятиях и транспорте.

Выделено 10 соединений ПАУ, проявляющих повышенную канцерогенную, мутагенную и токсичную активность и потенциально опасных для животных и человека, такие как бенз[а]антрацен, бенз[b]флуарантен, бенз[а]пирен (БП), дибенз[a,h]антрацен, индено[1,2,3-cd]пирен (Nadala, 2004). Сажа, каменноугольный деготь, минеральные масла, в составе которых обнаружены большие количества ПАУ, давно признаны для человека канцерогенами, вызывающими у работающих с ними опухоли кожи и респираторного тракта. Установлено, что $60 \%$ глобальной эмиссии бенз[а]пирена приходится на процессы, связанные со сжиганием угля (Ровинский, 1988).

Современные данные о накоплении полиаренов растениями в основном касаются вопросов ремедиации загрязненных почв. В настоящее время поглощение ПАУ из почвы и атмосферы наиболее изучено для культурных растений, для дикорастущих - сведения немногочисленны (Загрязнение почвенно-растительного..., 2012; Закономерности биоаккумуляции..., 2012). Наряду со сведениями о поглощении растениями полиаренов из почвы (Contamination of polycyclic..., 2014), имеются данные об отсутствии такого поглощения (Содержание бенз[а]пирена..., 1979). Некоторые авторы утверждают, что накопление полиаренов в надземных органах растений происходит в основном из атмосферы, а не из почвы. Эксперименты по выращиванию риса как в тепличных (Studies on the sources..., 2009), так и в естественных (Accumulation and..., 2004) условиях показали тесную корреляцию содержания полиаренов в воздухе и в надземной биомассе. Анализ литературы позволяет констатировать, что накопление полиаренов растениями зависит от их видовой принадлежности. Из почвы растения накапливают преимущественно легкие полиарены. Данные литературы тесно согласуются с данными, полученными нами для разных видов растений таежной и тундровой зон (Закономерности биоаккумуляции..., 2012).

Отметим, что при оценке экологического состояния экосистем тундровой зоны мало внимания уделяют определению уровня загрязнения растительности в районах, подверженных воздействию угледобывающей промышленности. Так, были проведены комплексные исследования уровня загрязненности Печорского бассейна (в том числе Воркутинского района) в рамках которых было оценено содержание тяжелых металлов и ПАУ в донных осадках тундровых озер (Multiple indicators..., 2009). Мы располагаем ограниченной информацией о накоплении ПАУ в почвах тундровой зоны. Например, содержание бенз[а]пирена в черте г. Воркуты (полоса южных тундр) 
выше ПДК, а максимальные превышения достигают 80 ПДК (Дымов, 2013). Однако такие высокие значения определяет именно влияние городской среды, по ним нельзя судить об уровне загрязнения тундровых экосистем.

Исследования загрязнения полиаренами растительного покрова архипелага Шпицберген в районе пос. Баренцбург показали, что основным его источником являются аэрозоли, поступающие в окружающую среду с выбросами ТЭЦ. Авторами выявлено, что наиболее показательным индикатором аэрозольного загрязнения ПАУ воздуха является сообщество мхов с круглогодичным вегетационным периодом (Загрязнение почвенно-растительного..., 2012).

Тундровые экосистемы отличаются низкой устойчивостью к разного рода воздействиям. Определение содержания полиаренов в растениях тундровой зоны, находящихся под аэротехногенным влиянием угледобывающей промышлености, с целью оценки состояния тундровых фитоценозов является актуальной задачей современных экологических исследований.

\section{Материалы и методы исследования}

Исследования были проведены в Большеземельской тундре (Воркутинский район, Республика Коми), где распространена массивно-островная многолетняя мерзлота. Территория представляет собой полого-увалистую равнину в северной части Печорской низменности (бассейн верховьев р. Усы и ее притоков - рек Воркуты и Сейды), сложенную сильно дислоцированными палеозойскими породами, перекрытыми толщей наносов ледникового происхождения. Почвообразующие породы - четвертичные верхнеплейстоценовые гляциальные и флювиогляциальные отложения. В окрестностях Воркуты это покровные пылеватые суглинки мощностью менее 10 м, подстилаемые мореной (Атлас почв..., 2010). Район исследования относят к умеренно континентальной атлантико-арктической климатической области, Воркутинскому климатическому району, его характеризуют суровая зима и относительно прохладное лето. Среднегодовая температура воздуха по метеостанции г. Воркуты составляет $5.8{ }^{\circ} \mathrm{C}$. Среднегодовое количество осадков - 550-600 мм (Атлас Республики Коми..., 1997). Исследования проводили в полосе южных тундр (Грибова, 1980). Зональный тип сообществ в данном районе - кустарниковые тундры. Наибольшее распространение имеют разные варианты ерниковых и ивняковых кустарниковых тундр, а также плоскобугристые болота. Характерной чертой растительного покрова является мозаичность, быстрая пространственная смена растительных группировок и, соответственно, изменчивость и комплексность их распределения (Атлас почв..., 2010).

В районе исследования распространены тундровые поверхностно-глеевые, торфянисто- и тор- фяно-тундровые глеевые почвы. Их морфологические особенности - это наличие поверхностной торфяной подстилки (10-30 см) и четко выраженного глеевого тиксотропного горизонта. Верхняя граница многолетней мерзлоты, служащая водоупором, залегает на глубине 55-80 см. Иллювиальная толща малой мощности, почвенный профиль слабо дифференцирован. Деформация почвенного профиля вызвана перемещением насыщенных влагой почвогрунтов при оттаивании и замерзании. Почвы характеризуются замедленным биологическим круговоротом и низкой биологической продуктивностью. Органогенные горизонты, верхняя часть иллювиальной и криогенной зон являются геохимическими барьерами. Почвы кислые. Гранулометрический состав тяжелый суглинок (Безносиков, 2012).

Для определения содержания ПАУ в органогенных горизонтах тундровых поверхностно-глеевых почв и растениях нижнего и верхнего ярусов кустарниковой тундры отбирали растения на фоновом участке (урочище Нерусовей-мусюр) и в районе действия угольной шахты «Юнь-Яга» с открытым способом добычи угля в 0.5 км от предприятия в северо-восточном направлении. На каждом участке для отбора растений нижнего яруса были заложены три пробных площадки (Родин, 1968). На каждой из них размером $100 \times 50$ см проводили пробоотбор почв органогенного горизонта и всех растений. После отбора растения взвешивали. У кустарничков отдельно анализировали корни, стебли и листья; у трав - надземную и подземную части. Для отбора растений верхнего яруса (ива шерстистая - Salix lanata L. и береза карликовая - Betula nana L.) на каждом участке были заложены три пробных площадки размером 500×500 см (Торлопова, 2003). На каждой из них пробоотбор проводили из пяти растений, формируя смешанный образец. Корни, стволики, ветви, листья и кору кустарников отбирали и анализировали отдельно. Образцы почв и растений высушивали при комнатной температуре $\left(20-25{ }^{\circ} \mathrm{C}\right)$ в течение месяца, измельчали и анализировали на содержание полиаренов.

В ходе проведения исследований на фоновом участке было отобрано 12 видов растений следующих групп - кустарники: Salix lanata и Betula nana; травянистые растения: Festuca ovina L. (овсяница овечья), Deschampsia caespitosa L. (щучка дернистая), Pyrola rotundifolia L. (грушанка круглолистная); кустарнички: Vaccinium myrtillus L. (черника), V. vitis-idaea L. (брусника), V. uliginosum L. (голубика) и Empetrum nigrum L. (водяника черная); мхи: Pleurozium schreberi Brid., Polytrichum commune L. и Dicranum undulatum Ehrh и два вида лишайников: Lobaria linita (Ach.) Rabenh. и Cladonia gracilis (L.) Willd. На загрязненном участке выявлено 10 видов растений кустарники: Salix lanata и Betula nana; травянистые растения: Festuca ovina, Deschampsia caes- 
pitosa, Pyrola rotundifolia, Chamaenerion angustifolium L. (иван-чай узколистный); кустарнички: Vaccinium vitis-idaea, V. uliginosum; мхи: Pleurozium schreberi, Polytrichum commune. Лишайники на загрязненных участках отсутствовали.

В основу определения ПАУ в почвах положены методики US EPA 8310, ПНД Ф 16.1:2:2.2: 3.39-03 (ПНД Ф 16.1:2:2. 2:3. 39-03., 2012), а также методики, описанные в научных работах (Закономерности формирования..., 2008). Для контроля точности использовали Standard Reference Material 1944 «New York/New Jersey Waterway Sediment" (National Institute of Standards \& Technology, USA). Методика выделения углеводородных компонентов нефти из растений опубликована нами ранее (Биоаккумуляция полициклических..., 2008). Для контроля точности определения содержания ПАУ в растениях в нашем исследовании применяли стандартный образец Certified reference material BCR-683 (European commission community bureau of reference). Kaчественное и количественное определение содержания ПАУ в почвах и растениях осуществляли методом обращенно-фазовой ВЭЖХ в градиентном режиме и спектрофлюориметрическим детек'тированием («Люмахром», фирма «Люмэкс», Россия). Идентификацию ПАУ проводили по времени удерживания и сравнения спектров флуоресценции выходящих из колонки компонентов со спектрами стандартных ПАУ. Статистическую обработку для оценки достоверности расхождений средних арифметических значений накопления полиаренов в почвах и растениях на фоновом и загрязненных участках проводили при помощи $\mathrm{t}$-критерия Стъюдента $(\mathrm{P}=0.95)$. Для проведения кластерного анализа использовали программу Statistica-6 (StatSofting, USA). При построении дендрограммы сходства для объедине- ния данных применяли метод Варда, в качестве способа определения сходства использовали евклидово расстояние.

\section{Результаты и обсуждение}

В ходе работы был проведен химический анализ угля шахты Юнь-Яга. В составе угля обнаружено 14 структур ПАУ (табл. 1): нафталин, флуорен, фенантрен, антрацен, флуорантен, пирен, бенз[а]антрацен, хризен, бензо[b]флуорантен, бензо[k]флуорантен, бенз[а]пирен, дибенз[a,h]антрацен, бенз[ghi]перилен и инденопирен. В угле шахты «Юнь-Яга» значительно преобладали легкие полиарены, такие как нафталин, флуорен и фенантрен. В меньшей степени были представлены пирен, хризен, бенз[b]флуорантен, бенз[а]пирен, бенз[ghi]перилен и инденопирен.

В погвах фоновых и загрязненных участков соответственно были идентифицированы 14 структур ПАУ: нафталин, флуорен, фенантрен, антрацен, флуорантен, пирен, хризен, бенз[а]антрацен, бензо[b]флуорантен, бензо[k]флуорантен, бенз[а]пирен, бенз[ghi]перилен, дибенз[а,h]антрацен и инденопирен.

В составе ПАУ в почвах на фоновых и загрязненных участках значительную часть предс'авляли легкие полиарены, их доля составляла 83$91 \%$ общей суммы ПАУ в почвах. На фоновом и загрязненном участках на нафталин, флуорен и фенантрен, преобладавшие в выбросах, приходилось 48 и 70\% суммарного содержания ПАУ соответственно. Общее содержание полиаренов на загрязненных участках превышало фоновые значения в 4 раза. Наибольшие кратности превышения (в 4-8 и 4-9 раз) были отмечены для легких (нафталин, флуорен, фенантрен) и тяжелых (дибенз[a,h]антрацен и инденопирен) ПАУ соответсвенно. Именно эти полиарены, за исключением

Содержание полиаренов в угле и почвах фонового и загрязненного участков, нг/г

Таблица 1

(20 Загрязненный участок, шахта «Юнь-Яга»

\begin{tabular}{|c|c|c|c|c|c|c|c|c|c|}
\hline \multirow{3}{*}{ ПАУ } & \multirow{2}{*}{\multicolumn{3}{|c|}{ Фонов ый участок, почва }} & \multicolumn{6}{|c|}{ Загрязненный участок, шахта «Юнь-Яга» } \\
\hline & & & & \multicolumn{3}{|c|}{ Почва } & \multicolumn{3}{|c|}{ Уголь } \\
\hline & Размах & Медиана & $\begin{array}{r}\text { Среднее } \\
\text { значение }\end{array}$ & Размах & Медиана & \begin{tabular}{|} 
Среднее \\
значение
\end{tabular} & Размах & Медиана & $\begin{array}{r}\text { Среднее } \\
\text { значение }\end{array}$ \\
\hline Нафрт алин & $25.7-32.8$ & 26.5 & 27.6 & $196.2-290.3$ & 216.0 & 226.3 & $1612.4-1746.0$ & 1642.6 & 1667.0 \\
\hline Флуорен & $29.2-52.5$ & 42.9 & 43.0 & $148.8-230.3$ & 165.5 & 177.0 & $1225.8-1343.4$ & 1266.0 & 1278.4 \\
\hline Фенантрен & $34.8-51.2$ & 37.7 & 40.7 & $162.5-245.5$ & 197.7 & 196.2 & 861.3-1039.7 & 915.8 & 938.9 \\
\hline Антрацен & $1.5-4.9$ & 2.5 & 3.0 & 5.7-12.0 & 8.7 & 8.8 & 55.3-96.7 & 73.8 & 75.3 \\
\hline Флуорантен & $0.0-37.2$ & 29.2 & 21.6 & $40.2-86.4$ & 53.0 & 60.5 & $54.0-75.6$ & 68.0 & 65.9 \\
\hline Пирен & $26.0-37.8$ & 31.1 & 31.6 & $46.8-86.0$ & 63.9 & 63.8 & $77.4-112.2$ & 106.4 & 98.7 \\
\hline Бенз[а]антрацен & 4.3-8.4 & 7.0 & 6.8 & $7.9-14.9$ & 10.8 & 11.1 & 28.4-33.3 & 32.6 & 31.5 \\
\hline Хризен & $9.5-19.4$ & 15.6 & 14.7 & $17.0-46.5$ & 34.3 & 33.2 & $375.0-435.6$ & 389.4 & 400.0 \\
\hline Бенз[b]фрлуорантен & $11.3-18.7$ & 14.0 & 14.4 & $21.1-42.4$ & 33.5 & 31.5 & $65.2-108.7$ & 98.3 & 90.7 \\
\hline Бенз[к]флуорантен & $3.8-6.2$ & 5.7 & 5.3 & $4.3-9.7$ & 6.2 & 6.9 & $9.9-11.9$ & 10.1 & 10.6 \\
\hline Бенз[а]пирен & $4.5-10.3$ & 8.2 & 7.8 & $3.1-12.9$ & 7.6 & 7.5 & $49.9-72.9$ & 62.3 & 61.7 \\
\hline Дибенз[a,h]ант рацен & $0.0-1.4$ & 0.0 & 0.5 & $1.1-9.5$ & 4.3 & 4.3 & $10.2-16.9$ & 14.8 & 14.0 \\
\hline Бенз[ghi]перилен & $5.9-11.8$ & 7.3 & 8.0 & $2.4-11.4$ & 5.3 & 6.5 & $99.7-108.0$ & 106.4 & 104.7 \\
\hline Индено[1,2,3-cd]пирен & $0.0-9.0$ & 3.6 & 4.0 & 7.7-21.0 & 18.4 & 16.3 & 213.7-242.3 & 230.0 & 228.7 \\
\hline$\Sigma П A У$ & $207.9-247.0$ & 231.0 & 229.6 & $699.1-1084.4$ & 811.0 & 849.9 & $4855.1-5248.4$ & 5094.2 & 5065.9 \\
\hline
\end{tabular}


дибенз[a,h]антрацена, преобладали в угле. Кратности превышения для остальных ПАУ были ниже и составляли 2-3 раза. Повышенное содержание хризена в выбросах шахты приводит к увеличению его содержания в почве в два раза по сравнению с фоновым участком. Повышенные содержания легких полиаренов в угле не приводили к резкому увеличению их содержания в почвах загрязненного участка. Такое явление может быть обусловлено высокой скоростью разложения легких полиаренов в почве. Культуры различных микроорганизмов могут эффективно трансформировать исключительно низкомолекулярные ПАУ, в то время как высокомолекулярные полиарены они окисляют слабо или не окисляют совсем (Белых, 2009; Efects of nutrient..., 2005). Легкие ПАУ, поступившие с угольной пылью в почву, могли подвергнуться частичной или полной трансформации, что снижало их содержание в почве.

В растениях фонового и загрязненного участков ПАУ также представлены преимущественно легкими структурами, такими как нафталин, флуорен и фенантрен - их доля в общей сумме ПАУ в растениях составляет 76-99\% (табл. 2). Это хорошо согласуется с данными литературы. Так, в растениях мятлика обыкновенного (Роа trivialis L.), растущих вдоль шоссе, выявлены только легкие полиарены (Polycyclic aromatic..., 2000). Более растворимые в воде низкомолекулярные ПАУ имеют лучший доступ в клетку (Шурубор, 2000). Высокое содержание ПАУ в растениях, вероятно, связано с тем, что легкие ПАУ являются необходимыми компонентами организма растений, участвующими в процессах обмена веществ. Физиологически активные соединения (витамины, гормоны) имеют в молекуле 2-3-ядерные структуры нафталинового и фенантренового типа. Природное сходство низкомолекулярных ПАУ с витаминами и гормонами также может оказывать определенное стимулирующее воздействие на проницаемость клеточных мембран (Ровинский, 1988).

Следует отметить, что на фоновом участке наибольшее содержание ПАУ было отмечено в талломах лишайника Cladonia gracilis и травянистых растениях - Deschampsia caespitosa и Festuca ovina. Лишайники отличаются способностью к биоаккумуляции и высокой чувствительностью к загрязнителям (A fast extraction..., 2006). Отсутствие лишайников на загрязненном участке, по-видимому, обусловлено повышенными концентрациями полиаренов в окружающей среде. Многолетние травянистые растения имеют мощную корневую систему, что способствует поглощению полиаренов из почвы. Мхи Pleurozium schreberi и Polytrichum commune характеризовались близкими значениями содержания как легких, так и тяжелых полиаренов. Среди кустарничков наибольшие количества полиаренов обнаружены у

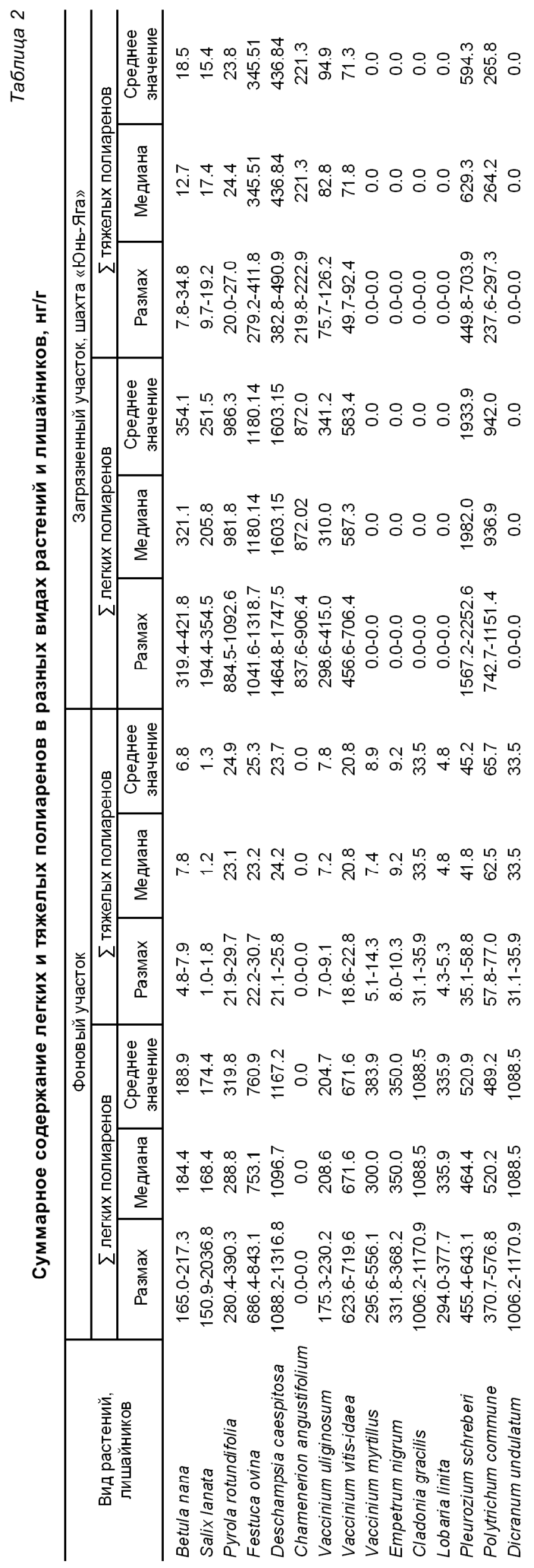


Vaccinium vitis-idaea, наименьшие - у V.uliginosum. Это, вероятно, обусловлено тем, что Vaccinium vitis-idaea как вечнозеленое растение могла накапливать полиарены из окружающей среды длительное время. Суммарное накопление полиаренов другими растениями травяно-кустарничкового яруса примерно одинаково и составляет 400-500 нг/г растения при содержании ПАУ в почве 230 нг/г. Наименьшее содержание ПАУ отличало растения верхнего яруса - Betula nana и Salix lanata, суммарное содержание ПАУ в них было ниже содержания ПАУ в почве.

Для загрязненного участка характерно повышение содержания полиаренов в растениях по сравнению с фоновыми значениями. Наибольшим суммарным накоплением полиаренов отличаются мхи (Pleurozium schreberi, Polytrichum commune) и травянистые растения (Deschampsia caespitosa, Festuca ovina, Pyrola rotundifolia). Следует отметить, что сосудистые растения характеризуются более высокой функциональной активностью по сравнению с мхами и интенсивно накапливают ПАУ в течение короткого вегетационного периода, в то время как ассимиляция полиаренов во мхах происходит в течение всего года. Максимальные кратности превышения фоновых значений 3-4 раза характерны для Pyrola rotundifolia и Pleurozium schreberi. Для остальных растений кратности превышения составляют приблизительно два раза. Содержание полиаренов в растениях Polytrichum commune в зоне аэротехногенного загрязнения в два раза ниже, чем в Pleurozium schreberi. Возможно, в условиях интенсивного поступления угольной пыли Pleurozium schreberi, имеющий большую площадь ассимилирующей поверхности, чем Polytrichum commune, поглощает больше полиаренов.

Следует отметить, что основную массовую долю ПАУ в растениях составляют легкие полиарены, но наибольшие кратности превышения содержания ПАУ для всех видов растений, за исключением Pyrola rotundifolia, характерны для тяжелых ПАУ. Из данных литературы известно, что содержание ПАУ во мхах, которые не имеют корневой системы, в значительной степени зависит от химического состава атмосферных осадков и от морфологических особенностей отдельных видов мхов (от площади поверхности ассимилирующих органов и их шероховатости, содержания воскоподобных веществ). Концентрации загрязняющих веществ в сосудистых растениях, имеющих развитую корневую систему, в большей степени обусловлены степенью загрязнения почвенного покрова (Загрязнение почвенно-растительного..., 2012). У Pyrola rotundifolia корневая система поверхностная, при этом листовая поверхность данного вида значительна, тто позволяет предположить поступление ПАУ в растения данного вида преимущественно с атмосферными выпадениями.
Превышение фоновых значений наиболее выражено для бенз[а]пирена, бенз[ghi]перилена, дибенз[а,h]антрацена и инденопирена (до 127 раз) и в меньшей степени для бензо[b]флуорантена, бензо[k]флуорантена. Для этих соединений, за исключением бенз[а]пирена и бенз[ghi]перилена, наблюдали значительное повышение содержания и в почве. Соединения, слабо представленные в почве, могли попадать в растения с атмосферными аэрозолями, так как в значительных количествах содержались в угле. Среди легких полиаренов наибольшие кратности превышения во всех видах растений отмечали для фенантрена, антрацена, пирена, хризена и бенз[а]антрацена (до 17 раз), что во многом связано с большим содержанием данных полиаренов в угле шахты. Значительные кратности превышения, полученные для тяжелых ПАУ, могут быть объяснены высоким фоновым содержанием легких полиаренов в растениях. Легкие полиарены могут образовываться в процессе жизнедеятельности растений. Тяжелые ПАУ в естественных условиях при отсутствии загрязнения содержатся в растениях в минимальных количествах.

Активная биоаккумуляции растениями Pleurozium schreberi как легких, так и 'яжелых полиаренов была показана для сельскохозяйственных районов Польши и национальных парков Аляски. При этом суммарные значения накопления ПАУ значительно варьировали - от десятков до тысяч нг/г на разных участках в пределах одного региона. Мох характеризовало повышенное накопление фенантрена по сравнению с другими ПАУ. Основную долю ПАУ в растениях составляли легкие ПАУ, высокомолекулярные ПАУ растения накапливали в меньшей степени (Interspecies..., 2009). В районе шахты «Юнь-Яга» накопление ПАУ растениями Pleurozium schreberi составляло 2528 нг/г, что в три раза больше содержания ПАУ в почве.

Следует отметить, что для всех растений загрязненного участка выявлена статистически значимая корреляция по содержанию ПАУ с почвой $(\mathrm{r}=0.60-0.91)$ и с углем $(\mathrm{r}=0.64-0.96)$. Максимальные значения коэффициента корреляции выявлены для Pyrola rotundifolia и Salix lanata, для остальных растений его значения близки и не превышают $r=0.74$. Содержание бенз[а]пирена в растениях изменяется подобно общему содержанию ПАУ. Накопление бенз[а]пирена растениями разных видов на фоновом участке не превышало 10 нг/г при его содержании в почве 8 нг/г. Значения содержания бенз[а]пирена в почве, некоторых растениях (Pleurozium schreberi, Polytrichum commune, Dicranum undulatum, Festuca ovina) и лишайниках (Cladonia gracilis) практически одинаковы (от 7 до 10 нг/г), тто позволяет рассматривать их в качестве потенциальных индикаторов содержания бенз[а]пирена в почве. 
Близкие уровни содержания полиаренов в почве и мхах в основном обусловлены тем, что именно за счет разложения мхов, преобладающих в биомассе тундровых фитоценозов, происходит формирование почвенного покрова. Festuca ovina активно накапливает ПАУ из почвы, благодаря хорошо развитой корневой системе. Содержание бенз[а]пирена в талломах Lobaria linita (3 нг/г) и растениях других модельных видов минимальное. Для подбора универсальных растений-индикаторов содержания ПАУ в почве необходимо проведение дополнительных исследований.

В районе действия шахты не выявлено повышенного содержания бенз[а]пирена в почве относительно фоновых значений, но при этом массовая доля бенз[а]пирена в растениях возрастает. Так, максимальные кратности превышения по сравнению с фоновыми значениями достигают 19 раз и отмечены для Deschampsia caespitosa. Это свидетельствует о большом вкладе атмосферного загрязнения в состав ПАУ растений в районах распространения угледобывающей промышленности. Минимальное накопление бенз[а]пирена характерно для кустарников и кустарничков загрязненного участка. Для Vaccinium vitis-idaea выявлено снижение содержания бенз[а]пирена по сравнению с фоновым участком. Это обусловлено в основном поступлением полиаренов в растения данного вида через корневую систему, так как аэрозольному поступлению препятствует мощный восковой налет на листьях.

Наибольшая массовая доля ПАУ в растениях полосы южной тундры была идентифицирована для Pleurozium schreberi, который составлял основную долю фитомассы на исследуемых площадках (табл. 3). Его вклад в потребление ПАУ достигал 56 и $52 \%$ от суммарного накопления для фонового и загрязненного участков соответственно. Высоким накоплением полиаренов на обоих участках отличались Betula nana и Salix lanata. Их доля в поглощении ПАУ в суммарном накоплении составляет на 19 и $26 \%$ на фоновом и загрязненном участках соответственно. Из травянистых растений значительный вклад в накопление полиаренов вносила Deschampsia caespitosa. Для загрязненного участка отмечен повышенный вклад в накопление ПАУ Pyrola rotundifolia и Chamaenerion angustifolium. На фоновом участке значительные количества ПАУ накапливаются в Polytrichum commune. Роль остальных растений в выносе ПАУ минимальна. Следует отметить, что для фонового и загрязненного участков суммарное содержание ПАУ (в расчете на единицу площади) в растениях ниже, чем запасы ПАУ в почве, в два и девять раз соответственно. Загрязнение почв полиаренами приводит к угнетению растительности, снижению ее биомассы, обеднению видового состава и, следовательно, к снижению величин общего выноса полиаренов растениями на единицу площади по сравнению с фоновым участком при повышении уровня аккумуляции ПАУ растениями на единицу массы.

Таким образом, данные о содержании ПАУ в угле, органических горизонтах почв и растениях свидетельствуют о том, что полиарены во всех исследованных объектах представлены в основном легкими структурами. Максимальный прирост ПАУ на загрязненных участках выявлен для тяжелых полиаренов. Наибольшим накоплением полиаренов в зоне техногенеза отличались растения Pleurozium schreberi и Pyrola rotundifolia. Pleurozium schreberi вносил основной вклад (более $50 \%$ ) в накопление полиаренов растениями полосы южной тундры в расчете на единицу площади.

Изучение содержания ПАУ в органах растений показало, что для Vaccinium uliginosum, $V$. myrtillus, V. vitis-idaea и Empetrum nigrum накопление ПАУ выше в листьях, чем в стеблях и корневой системе. На фоновом и загрязненном участках суммарное накопление ПАУ в листьях Vaccinium uliginosum превышало их содержание в стеблях и корнях в 2-4 раза. Для V. vitis-idaea выявлено незначительное превышение (1.1 раза). Растения Vaccinium myrtillus и Empetrum nigrum были обнаружены только на фоновом участке: для Vaccinium myrtillus превышение содержания

Вклад различных видов растений в накопление ПАУ

Таблица 3 в тундровых фитоценозах

\begin{tabular}{|c|c|c|c|c|}
\hline \multirow[t]{2}{*}{ Виды растений и лишайников } & \multicolumn{2}{|c|}{ Фоновый участок } & \multicolumn{2}{|c|}{$\begin{array}{c}\text { Загрязненный } \\
\text { участок, шахта } \\
\text { «Юнь-Яга» }\end{array}$} \\
\hline & $\mathrm{H} \Gamma / \mathrm{M}^{2}$ & $\%$ & $\mathrm{H} \Gamma / \mathrm{M}^{2}$ & $\%$ \\
\hline Betula nana & 45337 & 8.9 & 86319 & 19.0 \\
\hline Salix lanata & 51187 & 10.0 & 77728 & 17.1 \\
\hline Pyrola rotundifolia & 1286 & 0.3 & 8012 & 1.8 \\
\hline Festuca ovina & 4466 & 0.9 & 8322 & 1.8 \\
\hline Deschampsia caespitosa & 36039 & 7.1 & 15979 & 3.5 \\
\hline Chamerion angustifolium & - & 0.0 & 13920 & 3.0 \\
\hline Vaccinium uliginosum & 12410 & 2.4 & 4010 & 0.9 \\
\hline Vaccinium vitis-idaea & 739 & 0.1 & 3164 & 0.7 \\
\hline Vaccinium myrtillus & 19217 & 3.8 & - & - \\
\hline Empetrum hermaphroditum & 2730 & 0.5 & - & - \\
\hline Cladonia gracilis & 1646 & 0.3 & - & - \\
\hline Lobaria linita & 363 & 0.1 & - & - \\
\hline Pleurozium schreberi & 282636 & 55.5 & 235888 & 52.0 \\
\hline Polytrichum commune & 45429 & 8.9 & 690 & 0.2 \\
\hline Dicranum undilatum & 6177 & 1.2 & - & \\
\hline ¿ПАУ в растениях и лишайниках & 509660 & 100.0 & 454035 & 100.0 \\
\hline 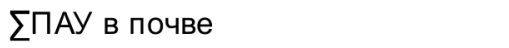 & 114814 & 100.0 & 4250000 & 100.0 \\
\hline
\end{tabular}


ПАУ в листьях над стеблями и корнями составляет 2.0-3.0 раза, для Empetrum nigrum - 1.51.8 раза. Отметим, что для Vaccinium myrtillus сходные закономерности в накоплении полиаренов выявлены и для таежной зоны (Закономерности биоаккумуляции..., 2012). Сосредоточение основной массы ПАУ в листьях Vaccinium uliginosum и V. myrtillus во многом обусловлено их листопадностью. Загрязнители концентрируются главным образом в вакуолях растительных клеток и сбрасываются вместе с листьями. ПАУ могут попадать в растение не только из почвы, но и из атмосферы и проникать в листовую пластинку через устьица. Для Vaccinium myrtillus выявлено повышенное содержание легких ПАУ в ягодах, из тяжелых ПАУ в ягодах был обнаружен только бенз[к]флуорантен, причем в небольших количествах. Vaccinium vitis-idaea и Empetrum nigrum - вечнозеленые растения, накопление ПАУ в их листьях происходит в меньшей степени. Проникновению полиаренов из атмосферы мог препятствовать восковой налет на листьях.

Для травянистых растений Festuca ovina и Deschampsia caespitosa на фоновом и загрязненном участках выявлено преимущественное накопление всех ПАУ в подземной час'ти рас'тений. Кра'тности превышения суммарного содержания ПАУ для фоновых и загрязненных участков составляют 2.0-2.5 и 3.0-5.0 раза соответственно. Для отдельных полиаренов кратности превышения могут достигать 40.0 раз. Базипетальная направленность в накоплении ПАУ свидетельствует об активном поглощении полиаренов из почвы.

Исследование накопления полиаренов разными органами растений кустарникового яруса показало, что для Betula nana на фоновых участках характерно следующее распределение ПАУ: листья > ветви $>$ корни $>$ кора $>$ стволики, для загрязненных - листья > кора > ветви $>$ корни $>$ стволики. При отсутствии загрязнения содержание ПАУ в коре растений минимально. В условиях техногенеза характер накопления полиаренов растениями изменялся. В зонах действия угольных шахт в 2.0 раза увеличилось содержание полиаренов в коре и листьях растений. Содержание ПАУ в ветвях и стволиках и корнях растений фонового и загрязненного участков примерно одинаково. Сходные данные получены для Salix lanata (табл. 3). На загрязненном участке в 4.0 раза возрастало содержание полиаренов в листьях кустарника. При этом их содержание в стволиках, коре и ветвях и корнях практически не отличалось от фоновых значений. Этот факт свидетельствует об отсутствии поглощения полиаренов. Полиарены при загрязнении поступают на поверхность надземных органов кустарников из атмосферы и аккумулируются на поверхности. Накопление ПАУ происходит и в корневой системе растений, но активного транспорта полиаренов из корней в надземные органы не наблюда- ли. Повышенное содержание полиаренов в листьях кустарников при их низкой концентрации в стволиках и ветвях свидетельствует об активном поступлении ПАУ на листовую поверхность в районе действия шахты «Юнь-Яга». Явно выраженное повышение содержания полиаренов в коре Betula nana обусловлено меньшей облиственностью кустарников данного вида по сравнению c Salix lanata. Листья Salix lanata почти полностью покрывают стволики, хорошо развитая листовая поверхность препятствует проникновению ПАУ из атмосферы на поверхность коры.

Таким образом, полученные результаты позволили предположить, что особенности накопления полиаренов растениями зависят от свойств растений (жизненной формы, облиственности, расположения корневой системы, ритма развития) и условий произрастания. Это объясняется различными механизмами усвоения, накопления, метаболизма и выведения загрязняющих веществ, которые могут варьировать в условиях техногенеза и при отсутствии загрязнения.

Для травянистых растений с их мощной корневой системой характерно накопление полиаренов в корнях. В листопадных кустарничках основная масса полиаренов концен'рируется в листьях. В растениях верхнего яруса распределение полиаренов по органам на фоновом к загрязненном участках разное. Минимальное накопление ПАУ в стволиках и ветвях кустарников на загрязненных участках свидетельствует о поверхностном загрязнении данных растений атмосферными аэрозолями.

Кластерный анализ накопления полиаренов растениями разных видов подтверждает факт, что биоаккумуляция ПАУ во многом связана со структурными особенностями растений (см. рисунок). Наибольшее сходство в поглощении ПАУ было характерно для модельных кустарников Betula nana и Salix lanata, которые могли поглощать значительное количество полиаренов из атмосферы и характеризовались наименьшим накоплением полиаренов по сравнению с другими исследованными растениями. Высокая степень сходства выявлена для кустарничков (Vaccinium vitisidaea и V. uliginosum) и для травянистых растений с мощной корневой системой (Festuca ovina и Deschampsia caespitosa). Для травянистых растений характерно накопление значительных количеств полиаренов из почвы, что доказывает повышенное содержание ПАУ в корнях. Для кустарничков характерно как корневое поглощение ПАУ, так и накопление из атмосферы через листовую поверхность. Следует отметить высокую степень сходства в накоплении полиаренов у Vaccinium uliginosum и травянистого растения Chamaenerion angustifolium. По-видимому C. angustifolium с большой поверхностью листьев и мощной корневой системой, как и кустарнички, мог накапливать полиарены из почвы и атмо- 
сферного воздуха. Из-за воскового налета на листьях, который способствует более легкому смыванию полиаренов с листовой поверхности и усложняет поглощение ПАУ из атмосферы, Vaccinium vitis-ida$e a$ поглощает ПАУ в меньшей степени, чем вышеприведенные виды растений, поэтому сходство Vaccinium vitis-idaea c Vaccinium uliginosum менее выражено. Довольно высокая степень сходства в поглощении ПАУ проявляется у Polytrichum commune и Pyrola rotundifolia. Оба растения низкорослые вечнозеленые, Pyrola rotundifolia с маломощной подземной частью, Polytrichum commune не имеет настоящих корней. Данные виды характеризуются повышенным накоплением полиаренов, вероятно, поглощают ПАУ в большей степени из атмосферы. Присутствует некоторая степень сходства в накоплении ПАУ Polytrichum commune и Pyrola rotundifolia c накоплением полиаренов кустарничками. Известно, что неко'торые морфологи о'тнося'т виды рода Pyrola не к травам, а к кустарничкам. Закономерности накопления полиаренов в Pleurozium schreberi близки к таковым у травянистых растений, хотя основной вклад в поглощение ПАУ Pleurozium schreberi ввиду отсутствия настоящих корней вносит поступление полиаренов из атмосферы. Возможно, объединение данных видов в одну группу связано с повышенными концентрациями ПАУ, характерными для растений этого кластера.

\section{Заключение}

В растениях полосы южной тундры были обнаружены 15 индивидуальных ПАУ: нафталин, аценафтен, флуорен, фенантрен, антрацен, флуорантен, пирен, хризен, бенз[а]антрацен, бензо[k]флуорантен, бенз[а]пирен, бенз[ghi]перилен, бензо[b]флуорантен и дибенз[a,h]антрацен. В угле шахты «Юнь-Яга» и почвах исследованных участков присутствовали все перечисленные ПАУ, кроме аценафтена. Доля низкомолекулярных ПАУ (нафталин, флуорен и пирен) в угле, органогенных горизонтах почв и растениях составляет 76-99\% . Суммарное содержание ПАУ в почвах загрязненного участка превышало фоновые значения в 4.0 раза. Максимальным накоплением ПАУ в зоне действия шахты отличались мхи и травянистые растения. Для растений максимальные кратности превышения фоновых значений составляли 3.0-4.0 раза и были выявлены для Pleurozium schreberi и Pyrola rotundifolia. Наибольшие кратности превышения содержания ПАУ в почвах и растениях выявлены для тяжелых ПАУ, что связано с их минимальным содер- жанием на фоновых участках. Содержание бенз[а]пирена в растениях изменялось подобно изменению суммарного содержания полиаренов.

Наибольшая массовая доля ПАУ в растениях полосы южной тундры приходится на Pleurozium schreberi. Его вклад в накопление ПАУ составлял 52-56\% от суммарного значения. Доля кустарников в накоплении полиаренов составляет 19$26 \%$ и достигает наибольших значений на загрязненных участках в связи с низкой биомассой растений нижнего яруса. Вклад растений кустарникового яруса в суммарное накопление IIAУ растениями незначителен ввиду их низкой способности накапливать полиарены. На загрязненном участке выявлено снижение суммарного выноса полиаренов из почвы, что обусловлено обеднением видового состава и снижением биомассы растений в условиях техногенеза.

Распределение полиаренов по органам модельных растений неравномерное и определяется как морфологией растений и особенностями биохимических процессов, протекающими в них, так и уровнем загрязнения. Мхи и лишайники с развитой ассимилирующей поверхностью поглощают ПАУ из атмосферы в течение всего года, в то время как травы и листопадные кустарнички лишь в течение вегетационного периода. Для травянистых растений выявлена активная биоаккумуляция полиаренов корнями. Кустарнички равномерно накапливают полиарены из почвы и атмосферы. В накопление ПАУ растениями кустарникового яруса большой вклад вносит атмосферное загрязнение. Мы предполагаем, что полиарены при загрязнении поступают на поверхность кустарников из атмосферы и аккумулируются в верхнем слое тканей, не проникая внутрь. Накопление ПАУ кустарниками происходит и через их корневую систему, но активной миграции полиаренов из корней в надземные органы не 
наблюдали. Для дальнейшего изучения поступления полиаренов в растения необходимо проведение дополнительных исследований загрязнения снежного покрова и атмосферных аэрозолей полиаренами. Необходимо также изучение биологических особенностей исследуемых видов, например, расчет таких показателей, как индекс листовой поверхности.

Работа выполнена в ралках госбюджетной телы "Пространственно-временные закономерности форлирования торфяных почв на европейскол северо-востоке России и их трансфорлация в условиях меняющегося климата и антропогенного воздействия" ( № Гр 115020910065).

\section{ЛИТЕРАТУРА}

Атлас почв Республики Коми / Отв. ред. А. И. Таскаев. - Сыктывкар, 2010. - 356 с.

Атлас Республики Коми по климату и гидрологии / Отв. ред. А. И. Таскаев. - М., 1997. - 116 с.

Безносиков, В. А. Фракционно-групповой состав гумуса криогенных поверхностно-глеевых и гидроморфных почв Большеземельской тундры / В. А. Безносиков, Е. Д. Лодыгин // Вестн. СПбгУ. Сер. 3. Биол. - 2012. - Вып. 1. - С. 107-120.

Белых, Л. И. Распределение полициклических ароматических углеводородов в системе почва-растение / Л. И. Белых // Почвоведение. - 2009. № 9. - Р. 1083-1089.

Биоаккумуляция полициклических ароматических углеводородов в системе почва-растение / Е. В. Яковлева, В. А. Безносиков, Б. М. Кондратенок, Д. Н. Габов, М. И. Василевич // Агрохимия. 2008. - № 9. - С. 66-74.

Грибова, С. А. Растительность европейской части СССР / С. А. Грибова, Т. И. Исаченко, Е. М. Лавренко. - Л. : Наука, 1980. - 236 с.

Дымов, А. А. Свойства почв и почвоподобных тел г. Воркута / А. А. Дымов, Д. А. Каверин, Д. Н. Габов // Почвоведение. - 2013. - № 2. - С. 240248.

Закономерности биоаккумуляции полициклических ароматических углеводородов в системе почварастения биоценозов северной тайги / Е. В. Яковлева, В. А. Безносиков, Б. М. Кондратенок, Д. Н. Габов // Почвоведение. - 2012. - № 3. - С. 356367.

Закономерности формирования полициклических ароматических углеводородов в почвах северной и средней тайги / Д. Н. Габов, В. А. Безносиков, Б. М. Кондратенок, Е. В. Яковлева // Почвоведение. - 2008. - № 11. - С. 1134-1143.

Загрязнение почвенно-растительного комплекса в окрестностях рудника "Баренцбург» полициклическими ароматическими углеводородами / Б. Н. Демин, А. П. Граевский, А. С. Демешкин, С. В. Власов // Арктика: экология и экономика. - 2012. № 3 (7). - С. 62-73.

Клар, Э. Полициклические ароматические углеводороды / Э. Клар. - М. : Химия, 1971. - Т. 1, 2. 457 с., 454 c.

ПНД Ф 16.1:2:2. 2:3. 39-03. (2003). МВИ массовой доли бенз[а]пирена в пробах почв, грунтов, донных отложений и твердых отходов методом ВЭЖ Х с использованием жидкостного хроматографа «Люмахром». - М., 2012. - 27 с.
Ровинский, Ф. Я. Фоновый мониторинг полициклических ароматических углеводородов / Ф. Я. Ровинский, Т. А. Тенлицкая, Т. А. Алексеева. Л. : Гидрометеоиздат, 1988. - 224 с.

Родин, Л. Е. Методические указания к изучению динамики и биологического круговорота в фитоценозах / Л. Е. Родин, Н. П. Ремцов, Н. И. Базилевич. - Л. : Наука, 1968. - 143 с.

Содержание бенз[а]пирена в почвах и растениях Эстонии / И. А. Велдре, М. А. Раху, А. Р. Итра, А. П. Ильницкий, Л. П. Паальме // Растения и химические канцергоны / Отв. ред. Э. И. Слепян. Л. : Наука, 1979. - С. 101.

Торлопова, Н. В. Влияние полютантов на хвойные фитоценозы (на примере Сыктывкарского лесопромышленного комплекса) / Н. В. Торлопова, Е. А. Робакидзе. - Екатеринбург, 2003. - 142 с.

Шурубор, Е. И. Полициклические ароматические углеводороды в системе почва-растение района нефтепереработки (Пермское Прикамье) / Е. И. Шурубор // Почвоведение. - 2000. - № 12. - С. 15091514 .

A fast extraction technique for extracting polycyclic aromatic hydrocarbons (PAHs) from lichens samples used as biomonitors of air pollution: Dynamic sonication versus other methods / C. Domeno, M. Blasco, C. Sanchez, C. Nerin // Analyt. Chim. Acta, 2006. - Vol. 569. - P. 103-112.

Accumulation and distribution of polycyclic aromatic hydrocarbons in rice (Oryza sativa) / S. Tao, X. C. Jiao, S. H. Chen, W. X. Liu, R. M. Coveney, L. Z. Zhu, Y. M. Luo // Environm. Pollution. - 2004. Vol. 320. - P. 11-24.

Contamination of polycyclic aromatic hydrocarbons (PAHs) in surface sediments and plants of mangrove swamps in Shenzhen, China / F. Li, X. Zeng, J. Yang, K. Zhou, Q. Zan, A. Le, N.F.Y. Tam // Marine Pollution Bull. - 2014. - Vol. 85. - № 2. - P. 590-596.

Efects of nutrient and temperature on degradation of petroleum hydrocarbons in contaminated subAntarctic soil / F. Coulon, E. Pelletier, L. Gourhant, D. Delille // Chemosphere. - 2005. - Vol. 58. P. 1439-1448.

Interspecies and interregional comparisons of the chemistry of PAHs and trace elements in mosses $\mathrm{Hy}$ locomium splendens (Hedw.) B.S.G. and Pleurozium schreberi (Brid.) Mitt. from Poland and Alaska / Z. M. Migaszewski, A. Galuszka, J. G. Crock, P. J. Lamothe, S. Dolegowska // Atmospheric Environmt. - 2009. Vol. 43. - P. 1464-1473.

Multiple indicators of human impacts on the environment in the Pechora Basin, north-eastern European Russia / T. R. Walker, P. D. Crittenden, V. A. Dauvalter, V. Jones, P. Kuhry, O. Loskutova, K. Mikkola, A. Nikula, E. Patova, V. I. Ponomarev, T. Pystina, O. Ratti, N. Solovieva, A. Stenina, T. Virtanen, S. D. Young // Ecol. Indicators. - 2009. - № 9. P. 765-779.

Nadala, M. Levels of PAHs in soil and vegetation samples from Tarragona County, Spain / M. Nadala, M. Schuhmachera, J. L. Domingo // Environm. Pollution. - 2004. - Vol. 132. - P. 1-11.

Polycyclic aromatic hydrocarbons in highway plants and soils. Evidence for a local distillation effect / C. Bryselbout, P. Henner, J. Carsignol, E. Lichtfouse // Analusis. - 2000. - Vol. 28. - № 4. - P. 290-293.

Studies on the sources of benzo[ $a]$ pyrene in grain and aboveground tissues of rice plants / P. Li, X. Li, F. Stagnitti, H. Zhanga, X. Linb, S. Zangc, J. Zhuoa, X. Xionga // J. Hazardous Materials. - 2009. -Vol. 162. - P. 463-468. 


\title{
ACCUMULATION OF POLYCYCLIC AROMATIC HYDROCARBONS IN PLANTS OF THE TUNDRA ZONE AT OPEN COAL MINE
}

\author{
E.V. Yakovleva, D. N. Gabov, V.A. Beznosikov \\ Institute of Biology of Komi Scientific Centre of the Ural Branch of the Russian Academy of Sciences, Syktyvkar \\ E-mail: kaleeva@ib.komisc.ru
}

\begin{abstract}
Using the method of highly-efficient liquid chromatography, we have revealed contents of polycyclic aromatic hydrocarbons (PAHs) in soils and plants in shrub south tundra region in conditions of aerotechnogenic pollution. Accumulation mechanisms of polyarenes by plants at the background area and in the impact zone of open coal mine were identified. By the obtained results, soils and plants of the background and aerotechnogenically polluted plots and coal were dominated by low molecular weight PAHs. The greatest difference between the background and the study plots was demonstrated by heavy PAHs because they were almost absent at the background area. Benz[a]pyrene concentration in plants changed in the same manner as the total concentration of PAHs. The highest weight portion of PAHs in plants of shrub tundra region belonged to Pleurozium schreberi. Contribution of upper layer plants to the total plant accumulation of PAHs was insignificant. Distribution of polyarenes in plants organs was unregular and depended on both plant biomorphology and pollution level. This work was supported by the state budget theme «Existential regularities of formation of peat soils in the European northeast of Russia and their transformation in the conditions of the changing climate and anthropogenous influence » (№ Гp.115020910065).
\end{abstract}

Key words: polycyclic aromatic hydrocarbons, coal-mining industry, tundra, soil, plants

\section{ХРОНИКА, СОБЫтИЯ, ФАКТЬ}

\section{ТАТЬЯНА НИКОЛАЕВНА ПЫСТИНА}

23 декабря празднует свой юбилей старший научный сотрудник лаборатории геоботаники и сравнительной фолористики Татьяна Николаевна Пыстина

Т.Н. Пыстина - специалист в области лихенологии и охраны растительного мира европейского северо-востока России. Она работает в Институте биологии с 1989 г. после окончания Сыктывкарского государственного университета. В 2000 г. успешно защитила диссертационную работу на соискание ученой степени кандидата биологических наук по теме «Лихенофлора равнинной части Республики Коми (подзоны южной и средней тайги)».

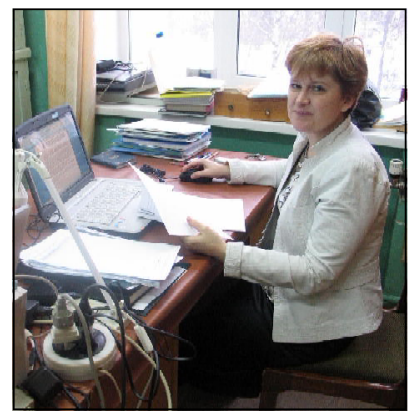

проектах, реализуемых в Институте биологии (SPICE, PRISM, PRIST).

Т.Н. Пыстина многие годы является членом и председателем комиссий государственной экологической экспертизы. Она уделяет большое внимание внедренческим работам, является ответственным исполнителем хозяйственных договоров, направленных на мониторинг воздействия промышленной деятельности на природные экосистемы.

Т.Н. Пыстина вносит большой вклад в экологическое воспитание школьников, студентов и населения Республики Коми, популяризацию научных знаний, участвует в

Сегодня Т.Н. Пыстина - широко известный специалистлихенолог. Она является автором и соавтором 140 опубликованных работ, в том числе 12 монографий. Ею внесен большой научный и практический вклад в исследования лихенобиоты Республики Коми. Получены данные о видовом разнообразии лишайников и их распространении в регионе, а также на сопредельных территориях - в Кировской области и Ненецком автономном округе. Для Республики Коми составлен аннотированный список видов, включающий более 1000 таксонов. Среди них есть виды, которые приводятся впервые для Европы, для европейского Северо-Востока, а более 400 видов выявлены Т.Н. Пыстиной впервые для республики. Татьяной Николаевной подготовлены очерки о редких видах лишайников и оригинальные рисунки для Красной книги Республики Коми. Особое внимание в своих исследованиях она уделяет вопросам изучения биот лишайников на особо охраняемых природных территориях. Сведения о редких видах лишайников, нуждающихся в охране, вошли в разделы коллективных монографиий «Атлас Республики Коми (2011), «Биологическое разнообразие ООПТ Республики Коми» (2011), «Природное наследие Урала» (2012). Результаты исследований создают теоретическую основу для решения проблем сохранения биологического разнообразия и устойчивого функционирования экосистем в изменяющихся условиях среды, вносят вклад в решение проблемы рационального использования и возобновления природных ресурсов.

Т.Н. Пыстина активно участвует в выполнении проектов по программам РФФИ, Президиума РАН, УрО РАН, а также Министерства природных ресурсов и охраны окружающей среды Республики Коми, является экспертом по ведению Красной книги Республики Коми. Она активно участвует в международных исследовательских проектах и развивает международное сотрудничество, была ведущим экспертом в ряде проектов ГЭФ-ПРООН, принимала участие в международных организации учебно-научной деятельности школьников и студентов. С 2004 по 2007 г. она совмещала научную деятельность с педагогической, разработала и читала на физикоматематическом факультете Коми государственного педагогического института (КГПИ) курс «Биология с основами экологии», для студентов факультета дополнительного образования института - курс «Экология организмов». Т.Н. Пыстина руководила выполнением семи дипломных работ студентов химико-биологического факультета Сыктывкарского университета и географо-биологического факультета. Она много лет является председателем жюри секции «Природное наследие Коми края. К туристскому мастерству» на ежегодно проводимых Республиканских краеведческих олимпиадах по школьному краеведению и Республиканских конференциях участников туристско-краеведческого движения «Отечество-земля Коми», участвовала в составе жюри школьных конференций, проводимых эколого-образовательным центром Института биологии «Снегирь». Регулярно проводит занятия в летних полевых школах юных натуралистов, оказывает консультации для слушателей Малой академии, учителей биологии образовательных школ г. Сыктывкара и других регионов Республики Коми, руководителей экологических кружков, преподавателей высших учебных заведений РК.

Т.Н. Пыстина награждена благодарностями Министерства образования Республики Коми, и Почетными грамотами Общества изучения Коми края, Коми научного центра УрО РАН, Профсоюза работников Российской академии наук, Министерства природных ресурсов и охраны окружающей среды Республики Коми.

Коллеги знают и ценят Т.Н. Пыстину как трудолюбивого, ответственного, вдумчивого специалиста, отзывчивого, внимательного человека, замечательную маму и бабушку и желают ей здоровья, новых открытий и свершений, талантливых учеников. 